Geo-Marine Letters

December, 2006; Volume 26, Number 6 ; P. 317-329

http://dx.doi.org/10.1007/s00367-006-0048-9

(c)XXX Springer Science+Business Media

The original publication is available at http://www.springerlink.com
Archimer, archive institutionnelle de l'Ifremer http://www.ifremer.fr/docelec/

\title{
The impact of the last European deglaciation on the deep-sea turbidite systems of the Celtic-Armorican margin (Bay of Biscay)
}

\author{
Sébastien Zaragosi ${ }^{1,{ }^{*}}$, Jean-François Bourillet ${ }^{3}$, Frédérique Eynaud ${ }^{1}$, Samuel Toucanne ${ }^{1}$, Benjamin \\ Denhard ${ }^{1}$, Aurélie Van Toer ${ }^{1,2}$ and Valentine Lanfumey ${ }^{1}$
}

(1) Département de Géologie et Océanographie, Université Bordeaux I, UMR 5805 EPOC, 33405 Talence Cedex, France

(2) Present address: Laboratoire des Sciences du Climat et de l'Environnement, Avenue de la Terrasse, 91198

Gif sur Yvette Cedex, France

(3) Laboratoire Environnements Sédimentaires, Géosciences Marines, Institut Français de Recherche pour I'Exploitation de la Mer (IFREMER), B.P. 70, 29280 Plouzané Cedex, France

*: Corresponding author : s.zaragosi@epoc.u-bordeaux1.fr

\begin{abstract}
:
The compilation of results obtained on three giant piston cores from the Whittard, Shamrock and Guilcher turbidite levees reveals a high-resolution stratigraphic record for the Bay of Biscay. Due to the abundance of reworked sediments in these sedimentary environments, a specific methodological approach, based on an X-ray-assisted subsampling phase associated with sedimentological, geochemical and micropalaeontological analyses, was implemented. With an accurate chronological framework, this multi-proxy investigation provides observations on the 'Fleuve Manche' palaeoriver and the British-Irish Ice Sheet (BIS) histories over the last 20,000 years. The results obtained highlight the direct influence of the decay of the BIS on the Bay of Biscay deep-sea clastic sedimentation during the last European deglacial phase. During this period, the annual BIS cycle of meltwater seems enough to generate seasonal turbidity currents associated with exceptional sedimentation rates in all the Celtic and Armorican turbidite systems. With very high sedimentation rates, the turbidite levees represent the main deep-sea clastic depositional area. Long coring combined with a very careful subsampling method can provide continuous high-resolution palaeoenvironmental signals.
\end{abstract}




\section{Introduction}

Previous studies have highlighted the fact that during the last European deglaciation, the brutal decay of the European Ice-Sheets produced an annual cycle of meltwater and iceberg release (Mojtahid et al. 2005; Lekens et al. 2005). Associated with abrupt changes in seasurface paleotemperatures, these annual events produce high sedimentation rates and "varvelike" layers of coarse-grained Iceberg-Rafted Detritus (IRD) on the Meriadzek Terrace and the Trevelyan Escarpment (Figure 1 and 2), both topographic highs of the Celtic margin (Zaragosi et al. 2001a). At the bottom of these rises, at a water depth of 4,000 to 4,900 m, lie two mid-sized deep-sea clastic systems: the Celtic and Armorican turbidite systems (Droz et al. 1999, Auffret et al. 2000, Le Suavé 2000, Zaragosi et al. 2000, 2001b). These systems are fed by more than 30 incised canyons along $500 \mathrm{~km}$ of the Celtic and Armorican Margins (Bourillet et al. 2003). These canyons, representing the major pathway for the deep-sea sedimentary supplies, have been grouped into four main submarine drainage basins (Figure 1; Bourillet et al. 2003). Each drainage basin developed distinct downstream submarine channels. These channels are bounded by natural levees built by deposition from turbidity flows that spill out of the channels. The submarine drainage basins are from west to east:

(a) The 'Grande Sole' Drainage Basin (GSDB) from the Goban to Brenot spurs. The Whittard channel-levee system is located basinward this catchment area.

(b) The 'Petite Sole' Drainage Basin (PSDB) from the Brenot to Berthois spurs. The Shamrock channel-levee system collects the sedimentary supplies from this catchment area.

(c) The 'La Chapelle' Drainage Basin (LCDB) from Berthois to Delesse spurs. Downstream, two channel-levee systems are developed: The Blackmud and Guilcher channellevee systems.

(d) The 'Ouest-Bretagne' Drainage Basin from the Delesse to Beaugé spurs, linked downstream to the Crozon channel levee system.

These four submarine drainage basins collect the sedimentary supplies of two distinct continental sources: (i) to the northwest, in relation with GSDB and partly PSDB, the Irish Sea and the British-Irish Ice Sheet (BIS) which developed extensively during the two last glacial maximum (Mojtahid et al. 2005; Mc Cabe and Clark, 1998; Scourse et al. 2000; Bowen et al., 2002) and (ii) to the east, in relation with PSDB, LCDB and OBDB, the 'Fleuve Manche', a large paleoriver system with a large catchment area including the continental paleo-drainage system of major west European rivers (Larsonneur et al. 1982; Gibbard, 1988; Lericolais et al. 2003; Bourillet and Lericolais 2003). To study sediment fluxes from the Irish Sea and the 'Fleuve Manche' paleoriver towards the deep-sea, long Calypso sedimentary cores were collected on the Celtic and Armorican turbidite systems during the SEDICAR and ALIENOR cruises onboard the RV Marion Dufresne II (Bourillet and Turon 2003; Turon et al. 2004). In this paper, results from multi-proxy analyses (i.e. physical, stratigraphical, geochemical and sedimentological) of sediment cores MD032690, MD042836 and MD042837 (Table 1) retrieved respectively on the Guilcher, Whittard and Shamrock levees, are compiled to reconstruct sedimentary processes and sediment transfers over the last 20,000 yrs, and to discuss the impact of the last European deglaciation on deep-sea clastic sedimentation. 


\section{Material and methods}

\section{X-ray imagery}

Thin slabs (15 mm thick) were sampled on cores MD032690, MD042836 and MD042837 at the Department of Geology and Oceanography (Bordeaux I University) and Xray analysed using the SCOPIX image processing tool (Migeon et al., 1999).

\section{Major elements measurements}

The measurement of major elements has been undertaken on core MD032690 by CORTEX X-Ray-Fluorescence analysis at a $5 \mathrm{~cm}$ resolution (Jensen et al. 1998). Among the 14 major elements measured with this method, we focus on those that are significant for environmental variability (i.e. $\mathrm{Ca}, \mathrm{Sr}$ and $\mathrm{Ti}$ ).

\section{Foraminifers - Stratigraphy}

To establish foraminifer stratigraphy, reworked sediments need to be avoided but on turbidite levees, turbidites are the most volumetrically significant facies. In consequence, the abundance of reworked sediments makes the sub-sampling phase delicate. Turbidite overflow sequences present a general thinning and fining-upward trend from very fine turbiditic sand (Td division of Bouma turbidite sequence; Bouma, 1962) to turbidite and hemipelagic clay interval (Tet and Teh divisions). In order to exclude reworked sediments in the $>150 \mu \mathrm{m}$ fraction, X-ray imagery was used to assure sampling in the hemipelagic clay intervals located between each turbidite sequences (Figure 3). The subsamples were sieved through a $150 \mu \mathrm{m}$ mesh. The residual fraction comprises primarily biogenic benthic and planktonic foraminifera and coarse terrigenous detrital grains (potentially Ice-Rafted Detritus, IRD).

Qualitative and quantitative analyses of the planktonic foraminifera were performed on the $>150 \mu \mathrm{m}$ fraction. Counting focused on the species Neogloboquadrina pachyderma sinistral, a morphotype which today dominates the North Atlantic polar environments. The stratigraphical framework of the cores is based on the combination of the $N$. pachyderma s. percentage curve and AMS ${ }^{14} \mathrm{C}$ dating (Table 2).

To obtain a precise age model, the $N$. pachyderma s. percentage curve acquired on the proximal core MD952002 (Figure 2; Zaragosi et al., 2001a) is compared with the percentage curve of the same species obtained on the studied cores. These different curves display a clear similarity (Figure 4). The age scale of core MD952002 was previously well constrained $\left(19^{14} \mathrm{C}\right.$ AMS dates between 0 and 30 kyr; Table 2; Grousset et al., 2000; Zaragosi et al., 2001a).

\section{Terrigenous characterization}

The coarse detrital grains were characterized and counted from all samples on the same fraction as the microfauna. These grains include all the lithic grains coarser than $150 \mu \mathrm{m}$ and contain IRD which indicates iceberg melt fluxes.

Subsamples on bulk sediment were taken for measurements of carbonate content using gasometric calcimetry, and grain size measurements using a Malvern MASTERSIZER S.

\section{Thin sections}

To obtain high-resolution sedimentological information, a modified impregnation protocol was adapted, for wet fine-grained sediments, from the method described by Bénard (1996). Fresh cores were sampled with oriented perforated aluminium boxes $(100 \mathrm{~mm} \times 45$ $\mathrm{mm} \times 13 \mathrm{~mm}$ ). The samples were subsequently dehydrated with a graded series of acetone water solutions ( $25 \%, 50 \%, 75 \%$ and $100 \%)$. The acetone is fully dried using a molecular sieve (4A pellets) under closed circuit with a peristaltic pump allowing continuous acetone circulation. After the acetone change, the subsamples were placed in plastic boxes with impregnating solution. This solution consists of a formulation of Crystic 17449 resin, acetone 
and catalyst (Butanox M50) at ratios of 100:15:0.85 per volume. Fluorescent dye (UVITEX $\mathrm{OB}$ at $0.73 \mathrm{~g} / \mathrm{l}$ ) was dissolved in the mixture to allow subsequent fluorescent light analysis. The plastic boxes then were placed in a desiccator at a pressure of 0.6 bar for two days. Samples were removed from the desiccator and left to polymerize for 4 weeks at room temperature, and finally under sunlight for 4 weeks to harden.

Vertical cross-sections were produced in the middle of the cured sediment/resin samples using a diamond saw. One side of each block was polished using a rotating lapidary unit with silicon carbide polisher (F320 and F500). The clean surfaces obtained were attached to $12 \times$ $4.5 \mathrm{~cm}$ microscope slides using Crystic resin, Butanox catalyst and hardening agent (Kovi NL-51P accelerator). The bonded blocks were cut to approximately $100 \mu \mathrm{m}$ using a precision saw (ESCIL LT-260) and thereafter hand polished to a thickness of $30 \mu \mathrm{m}$ using the rotating lapidary unit. Finally, coverslips were fixed on the thin sections using the collage resin mixture.

Thin-section images were acquired using a fully automated Leica DM6000 B Digital Microscope with multiple magnifications. Illumination in the ultraviolet band also allows fluorescence imaging.

\section{Results}

\section{Stratigraphy and sedimentation rates}

Figure 4 presents the $N$. pachyderma s. percentages of the studied cores. The main reworked sedimentary composition of turbidite levees is an obstacle to building accurate stratigraphic curves. The sub-sampling procedure (cf Materal and methods; Figure 3) used here to extract the hemipelagic signal permits the recovery of the hemipelagic layers avoiding the turbidite laminae. Therefore, the main paleoclimatic events of the Marine Isotopic Stages (MIS) 1 and 2 are distinctly recorded (i.e. the Holocene, Younger Dryas, Bølling-Allerød, Heinrich events $\mathrm{H} 1$ and $\mathrm{H} 2$ and the last European deglaciation phase).

Previously, the MD952002 core, located on the Meriadzek Terrasse was the sedimentary record with the highest sedimentation rates known in the Bay of Biscay (Zaragosi et al. 2001a). Cores MD032690, MD042836 and MD04283 present rates two to three time higher during the last 20,000 yrs.

\section{XRF results}

Sr (alkaline earth element) is fixed by calcifying organisms at the same time as Ca. For this reason, $\mathrm{Sr}$ is used in marine environments as a marker of strictly biogenic origin (Martin et al. 2004). Conversely, Ca can be supplied from terrigeneous sources (including feldspars, clays). In the MD032690 core, $\mathrm{Ca}$ is mainly sourced from biogenic $\mathrm{CaCO}_{3}$ as suggested by the covariation of the Ca and Sr data (Figure 5).

$\mathrm{Ti}$ is a common constituent of rocks such as gneisses or schists and therefore primarily indicates a terrigenous continental source. The $\mathrm{Ti} / \mathrm{Sr}$ ratio is used to discern terrigenous versus biogenic supplies. The Ti/Sr ratio shows elevated values during the last glacial stage and during the Younger Dryas. Bølling-Allerød and Holocene period are characterized by a low $\mathrm{Ti} / \mathrm{Sr}$ ratio $(<5)$. During the last glacial stage the Ti/Sr evolution is similar to the number of sediment laminae curve (Figure 5), i.e. high amount of laminae is synchronous with high $\mathrm{Ti} / \mathrm{Sr}$ ratio values. The highest $\mathrm{Ti} / \mathrm{Sr}$ ratios and occurrence of laminae are observed during the European deglaciaion event (between 13,870 - 15,060 yrs ${ }^{14} \mathrm{C} \mathrm{BP}$ ).

\section{Lithology}


Cores MD032690, MD042836 and MD042837 have been divided into five lithozones (Figure 4). These lithozones have been defined using photography, X-ray imagery, grain size measurements, $\mathrm{CaCO}_{3}$ content, XRF measurements and thin sections analysis.

Lithozone 1: homogenous structureless marly ooze.

Lithozone 1, observed in the upper part of the studied cores, presents high $\mathrm{CaCO}_{3}$ contents (between 30 and 60\%) and very low $\mathrm{Ti} / \mathrm{Sr}$ ratios. The sediments with homogeneous appearance are characterized by the absence of lithic grains in the $>150 \mu \mathrm{m}$ fraction and are associated with low sedimentation rates (about $18 \mathrm{~cm} / \mathrm{kyr}$ ).

The content of $N$. pachyderma s. is always lower than $8 \%$ and the amount of planktonic foraminifera shows enhanced values between 2,000 and 15,000 foraminifera per gram.

This lithozone forming the modern deep-sea Bay of Biscay seafloor has been interpreted on the Whittard, Shamrock and Guilcher turbidite levees as pelagic to hemipelagic drape deposits without significant terrigeneous supplies from the shelf.

Lithozone 2: homogeneous structureless clay with rare fine-bedded very fine sand, silt and clay sequences.

Lithozone 2 observed during the Bølling-Allerød, Younger Dryas and Early Holocene is characterized by intervals of homogeneous structureless clay interbedded with centimetric fine-grained turbidites. $\mathrm{CaCO}_{3}$ content is lower than $30 \%$. The $\mathrm{Ti} / \mathrm{Sr}$ ratio presents intermediate values except higher values during the Youger Dryas. These higher values are linked to the cold sea surface conditions of this event, with low biogenic production. The content of $N$. pachyderma s. presents values below 8\% except during the Younger Dryas cold event, and the amount of planktonic foraminifera per gram ranges between 300 during the Bølling-Allerød and 4000 during the Early Holocene.

For core MD032690, the sedimentation rate drops from high values during the BøllingAllerød $(176 \mathrm{~cm} / \mathrm{kyr})$ to low values $(18 \mathrm{~cm} / \mathrm{kyr})$ for the Early Holocene.

Lithozone 2 is interpreted as hemipelagic deposits with episodic fine-grained turbidite supplies.

Lithozone 3: laminated, very fine sand, silts, clay and ice-rafted rich layers.

Sediments of Lithozone 3 contain frequent sequences of thinning and fining upward very fine sand and silt laminae with sharp basal contact. Sometimes cross-stratifications (Figures 6a and 8) and ice-rafted rich millimetric clay layers are observed. The sequences of very fine sand and silt laminae are interpreted as fine-grained turbidites. Turbidite layers are thin ( 2 to 10 centimeter) and the layers rich in ice-rafted debris are often located just below the fine-grained turbidites.

Sediments in Lithozone 3 show low $\mathrm{CaCO}_{3}$ content $(13-30 \%)$ and an intermediate $\mathrm{Ti} / \mathrm{Sr}$ ratio. Lithozone 3 is synchronous with Heinrich events $\mathrm{H} 1$ (12,700 - 14,300 yrs ${ }^{14} \mathrm{C} \mathrm{BP}$; Zaragosi et al. 2001a) and H2 (19,700 - 22,300 yrs ${ }^{14} \mathrm{C}$ BP; Zaragosi et al. 2001a) and presents very high values in the $>150 \mu \mathrm{m}$ lithic grains fraction, and high sedimentation rates in core MD032690 during the Heinrich 1 event (about $375 \mathrm{~cm} / \mathrm{kyr}$ ). The $N$. pachyderma s. monospecific assemblage ( 100\%) indicates polar sea surface conditions, and the amount of planktonic foraminifera ranges between 100 and 800 foraminifera per gram.

Lithozone 3 reveals significant turbidite supply from the shelf associated with frequent ice rafting events.

Lithozone 4: Very fine bedded silt, clays and ice-rafted rich clay layers. 
Lithozone 4 presents a similar combination of turbidite and ice-rafting sequences to Lithozone 3. Compared to Lithozone 3, the thickness of fine-grained turbidite layers is low and the frequency of the ice-rafted rich laminae is high. Turbidites are very thin (about $1 \mathrm{~cm}$ ) and IRD layers are almost always located at the base and top of the fine-grained turbidites (figures 6b and 7). For core MD032690, the sedimentation rate presents extremely high values (about $1,123 \mathrm{~cm} / \mathrm{kyr}$ ).

Sediments of Lithozone 4 present low $\mathrm{CaCO}_{3}$ contents (13 - 19\%) and high Ti/Sr ratios. The $N$. pachyderma s. monospecific assemblage ( 100\%) indicates polar sea surface conditions. The amount of planktonic foraminifera ranges between 10 and 200 foraminifera per gram.

Lithozone 4, synchronous with the European deglaciation event $(14,300$ - 15,000 yrs ${ }^{14} \mathrm{C}$ BP; Zaragosi et al. 2001a; Mojtahid et al. 2005), reveals extremely important turbidite supply from the shelf associated with frequent ice rafting events.

Lithozone 5: fine bedded very fine sands, silt and clays.

Sediments of Lithozone 5 contain frequent sequences of thinning and fining upward very fine sand and silt laminae interpreted as fine-grained turbidite. Lithozone 5 with low $\mathrm{CaCO}_{3}$ content (between 13 and 24\%) presents an intermediate Ti/Sr ratio and a very low foraminifera concentration ( $<50$ foraminifera per gram).

Lithozone 5, observed on the Whittard and Guilcher levees during the main part of the Last Glacial Maximum (21,000 to 15,000 yrs ${ }^{14} \mathrm{C} \mathrm{BP}$ ), presents sedimentation rates of about $175-250 \mathrm{~cm} / \mathrm{kyr}$. The high variability of the $N$. pachyderma s. percentages (between 2 and 85\%) indicates high climatic variability during the Last Glacial Maximum.

\section{Discussion}

\section{The channel-levee morphology}

The Celtic and Armorican margin deep-sea environments include channels located southward of the drainage basins with two morphological types: (1) straight and relatively large (Shamrock, Brest and Crozon Channels) and (2) sinuous (Whittard and Guilcher channels). All these channels developed strongly asymmetrical bordering levees. The straight channels are 1,000-5,000 m wide, 50-80 km long and edged by 50-260 m high right levees. The sinuous channels are 1,500-2,500 m wide, 60-100 km long and edged by 70-270 m high right levees. The size of the majority of the levees is relatively constant (between 800 and 500 $\mathrm{km}^{2}$ ) except for the oversized Whittard levee which spread over more than $3,500 \mathrm{~km}^{2}$.

The comparison between the size of the levees and sedimentation rates of the studied cores reveals no relationship between levee development and Late Quaternary accumulation rates. Indeed, mean sedimentation rates on cores MD032690 (Guilcher Levee) and MD042836 (Whittard Levee) are comparable despite the surface area of the Whittard Levee that is seven times greater. The sediment composition is also similar for each levee as shown by the uniform lithozone organisation (Figure 4). Previous studies of several submarine channel levees (Skene et al. 2002) demonstrate an obvious relationship between levee architecture and channel dimension. Despite this relationship, no systematic variation between the Whittard, Shamrock and Guilcher levee sizes and sedimentation rates or sediment type is seen. In consequence, the possibility of allocyclic processes as sediment source and sedimentary process variability cannot explain the larger development of the Whittard levee. 
Autocyclic processes such as low avulsion rates and high levee stability seem more appropriate in explaining this greater size.

\section{Evolution of sedimentary processes}

The development of the Celtic and Armorican turbidite systems began during the Miocene (Droz et al. 1999). Core control in this study allows the reconstruction of the sedimentary history during the MIS 1 and 2 (0 - 22,000 yrs $\left.{ }^{14} \mathrm{C} \mathrm{BP}\right)$ only. During this period these systems do not appear to have been built-up with a gradual or constant sedimentary supply. The five observed lithozones indicate distinct episodes of growth characterized by several depositional processes.

It is expected that cores collected on turbidite levees record autocyclic processes related to the overall increase in channel relief through time (Manley et al. 1997). These autocyclic processes involve a fining and thinning-upward trend of the overflow sequences. However during the last 15,000 yrs ${ }^{14} \mathrm{C} \mathrm{BP}$, on the Guilcher, Shamrock and Whittard levees, the lithozone organisation depicts an opposite trend. Indeed the transitions between Lithozones 4 , 3 and 2 are characterized by a thickening-upward evolution of the turbidite sequences. The synchronous evolution on the whole margin therefore appears to be linked to allocyclic processes. These processes can be linked to the evolution of the sediment supply from the "Fleuve Manche" paleoriver and the BIS, as well as continent-deep ocean connection quality linked to the sea-level rise.

The stratigraphic framework established for the Guilcher, Shamrock and Whittard levees reveals synchronicity for the five characteristic lithozones (Figure 4). Sediments deposited on the levees during the main part of the LGM (21,000 to 15,000 yrs $\left.{ }^{14} \mathrm{C} \mathrm{BP}\right)$ are characterized by frequent fine-grained turbidites (Lithozone 5) and relatively high sedimentation rates. The sea-level low-stand associated with high fluvial flux related to heat and moisture supplies linked to North Atlantic Drift (Zaragosi et al. 2001a) seems to explain the observed high sedimentation rates. In this configuration, a wide spectrum of material was available to be transported to the deep-sea. This high sedimentary supply from the shelf was also contemporaneous with the existence of the Irish Sea ice stream, the main drainage conduit for the BIS (Scource et al. 2000; Richter et al. 2001). During the LGM, this ice stream, located in the vicinity of the St. Georges' Channel (Figure 1), flowed southward towards the Armorican and Celtic turbidite systems.

At 15,000 yrs ${ }^{14} \mathrm{C} \mathrm{BP}$, a major change in deposition pattern occurred on all turbidite levees. This change is characterized by the occurrence of ice-rafted deposits and by a significant increase in sedimentation rates and $\mathrm{Ti} / \mathrm{Sr}$ ratios (Lithozone 4). These changes, synchronous with the last European deglaciation event (Zaragosi et al. 2001a), indicate increased continental sediment supply associated with frequent deposition of ice-rafted debris. Between 15,000 and 14,200 yrs ${ }^{14} \mathrm{C}$ BP, similar ice-rafted deposits occur on the Trevelyan Escarpment and Meriadzek Terrace (Zaragosi et al. 2001a; Mojtahid et al. 2005), two tectonic topographic highs located in the same area (Figure 2). These deposits have been interpreted as annual marine "varves" related to the annual cycle of meltwater and iceberg release from the disintegrating BIS.

Thin sections of sediments of the deglaciation phase (Figures 6b and 7) reveal the link between turbidite and IRD-rich layers. According to sedimentation rates of about 1,123 $\mathrm{cm} / \mathrm{kyr}$, the thin section in Fig 6b (core MD032690 Guilcher levee) represents about 8.5 years of sedimentation. 11 ice-rafted laminae and 8 fine-grained turbidites are found. Each of the 6 central turbidites are bordered at the base and the top by ice-rafted rich laminae . Sharp basal contact and gradual upper top contact indicate that, in fact, one IRD layer, related to the same 
seasonal iceberg release, is divided in two by the turbidite unit (Fig 9). Thus, during the European deglaciation phase, the annual cycle of meltwater from the disintegrating BIS appears enough to have generated seasonal turbidite flows in the whole of the Celtic and Armorican turbidite system catchment areas through all the canyons of respectely the GSDB, PSDB and LCDB.

During this period, the connection between the two potential continental sedimentary sources (i.e. the "Fleuve Manche" paleoriver and the Irish Sea glacial systems) and the canyons had to be efficient. Indeed the synchronicity between the turbidite flows and iceberg release indicates a very short sedimentary transit on the shelf. The significant increase of the sedimentation rates associated with the high $\mathrm{Ti} / \mathrm{Sr}$ ratio also attests to an intensification of the terrigenous transfers during this period.

Around 14,000 yrs ${ }^{14} \mathrm{C} \mathrm{BP}$, just before the Heinrich 1, a new synchronous change occurs in all studied turbidite levees. This change results in an increase in the thickness of the finegrained turbidites sequence, in the decrease in number of ice-rafted layers and the drops in sedimentation rates and $\mathrm{Ti} / \mathrm{Sr}$ ratios (Lithozone 3 ). The relationship between the ice-rafted layers and the fine-grained turbidites is not any more systematic and the fine-grained turbidites are thicker but less frequent. This evolution would represent the beginning of the connection efficiency deterioration between the fluvial continental systems and the canyon heads in relation to synchronous sea-level rise.

During the Bølling-Allerød, the ice-rafted deposits definitively disappear and the sedimentation rates decrease drastically (Lithozone 2). This drop, associated with a progressive scarcity of the fine-grained turbidite sequences, expresses the vanishing of the BIS and the progressive retreat of the fluvial systems on the shelf.

The transition to Lithozone 1 occurs during the Early Holocene (between 10,000 and 8,700 yrs $\left.{ }^{14} \mathrm{C} \mathrm{BP}\right)$. Lithozone 1 , characterized by the shutdown of overflow processes on the levees and the occurrence of an hemipelagic sedimentation, indicates the establishment of present day hydrodynamic conditions on the shelf. During the Late Holocene, the cessation of terrigeneous supply coincides with the marine invasion of the "Fleuve Manche" paleoriver (Bourillet et al. 2003) and could also be linked to the general reforestation of Western Europe.

\section{Conclusions}

The multi-proxy analysis of long cores on the Whittard, Shamrock and Guilcher turbidite levees highlights the direct influence of the decay of the BIS on the Bay of Biscay deep-sea clastic sedimentation. The chronological framework provides accurate observations on the "Fleuve Manche" and BIS recent histories. The annual BIS cycle of meltwater during the European deglaciation event $\left(15,000\right.$ and 14,200 yrs $\left.{ }^{14} \mathrm{C} \mathrm{BP}\right)$ generated seasonal turbidite flows associated with exceptional sedimentation rates on the whole Celtic and Armorican turbidite systems. Thin-section analysis revealed annual meltwater-induced-turbidite sequence consisting of IRD layers split in two by a fine-grained turbidite. The synchronicity between annual turbidite flow and iceberg release indicates a very short sedimentary transit on the shelf. The annual turbidite/IRD cycles suggest a direct and efficient connection between the "Fleuve Manche" paleoriver, the Irish Sea continental systems and the submarine canyons. The progressive scarcity of the fine-grained turbidite sequences associated with the vanishing of ice-rafted deposits during the Bølling-Allerød, expresses the collapse of the BIS and the progressive retreat of the fluvial systems on the shelf. Overflow processes on the levees stopped in the Early Holocene (10,000 and 8,700 yrs BP). Since then, hemipelagic sedimentation indicates modern hydrologic conditions on the shelf and the disappearance of the "Fleuve Manche" paleoriver. 
Acknowledgements

The authors are grateful to IPEV and the crew of the R/V Marion Dufresne II for their technical assistance during the Sedicar and Alienor cruises. We wish to thank Y. Balut for his assistance at sea and J. Duprat, G. Floch, B. Martin, J. St Paul, D. Poirier, R. Kerbrat, and O. Ther for their laboratory assistance. Thanks are due to W. Banks and W. Fletcher for assistance with language. We also thank L. Droz and M. Frenz for their very constructive reviews and comments. We acknowledge financial support by the EU-project PALEOSTUDIES (Contrat N HPRI-CT-2001-0124), the French Programme "GDR Marges" and ARTEMIS ${ }^{14} \mathrm{C}$ Accelerator Mass Spectrometry French Project. This is an U.M.R./ EPOC 5805 (Université Bordeaux I - C.N.R.S.) contribution nº 1607. 
References

Auffret GA, Zaragosi S, Voisset M, Droz L, Loubrieu B, Pelleau P, Savoye B, Bourillet J F, Baltzer A, Bourquin S, Dennielou B, Coutelle A, Weber N, Floch G (2000) Premières observations sur la mophologie et les processus sédimentaires récents de l'Eventail celtique. Océanologica acta 23(1):109-116

Bard E (1998) Geochemical and geophysical implications of the radiocarbon calibration. Geochimica Cosmochimica Acta 62:2025-2038

Bénard Y (1996) Les techniques de fabrication des lames minces de sol. Cah. Techn. I.N.R.A. $37: 29-42$

Bouma AH (1962) Sedimentology of some flysch deposits: a graphic approach to facies interpretation. Amsterdam, Elsevier, 168 pp

Bourillet J-F, Loubrieu B (1995) Carte bathymorphologique de la marge des entrées de la Manche au 1:250.000. IFREMER

Bourillet J-F, Lericolais G (2003) Morphology and seismic stratigraphy of the Manche paleoriver system, Western Approaches margin. In: Mienert J, Weaver PP. (eds) European Margin Sediment Dynamics: Side -Scan Sonar and Seismic Images. Springer, Berlin pp 229-232

Bourillet J-F, Reynaud J-Y, Baltzer A, Zaragosi S (2003) The "Fleuve Manche": the submarine formation from the outer shelf to the deep-sea fans. Journal of Quaternay Science 18:261-282

Bourillet J-F, Turon J-L (2003) Rapport scientifique de la mission MD133/SEDICAR. OCE/2003/04, 150 p. Les rapports de campagne à la mer, IPEV Brest

Bowen DQ, Phillips FM, McCabe AM, Knutz PC, Sykes GA (2002) New data for the Last Glacial Maximum in Great Britain and Ireland. Quaternary Science Reviews 21(13):89-101

Cremer M, Orsolini P, Ravenne C (1985) Cap-Ferret Fan, Atlantic Ocean. In: Bouma AH, Normark WR, Barnes NE (Eds) Submarine Fans and Related Turbidite Systems. Springer-Verlag, pp 113-120.

Droz L, Auffret GA, Savoye B, Bourillet JF (1999) L'éventail profond de la marge Celtique: stratigraphie et évolution sédimentaire. C.R. Acad. Sci. Paris 328:173-180

Faugères JC, Imbert P, Mézerais ML, Crémer M. (1998) Seismic patterns of a muddy contourite fan (Vema Channel, South Brazilian Basin) and a sandy distal turbidite deepsea-fan (Cap Ferret system, Bay of Biscay): a comparison. Sedimentary Geology 115:81-110

Gibbard PL (1988) The history of great northwest European rivers during the past three millions years. Phil. Trans. R. Soc. Lond. B318: 59-602

Grousset F, Pujol C, Labeyrie L, Auffret GA, Boelaert A, (2000) Were the North Atlantic Heinrich events triggered the behavior of the European ice sheet? Geology, 28(2):123126

Jansen JHF, Van der Gaast SJ, Koster B, Vaars AJ (1998) CORTEX, a shipboard XRFscanner for element analyses in split sediment cores. Marine Geology 151:143-153

Larsonneur C, Auffret JP, Smith AJ (1982) Carte des paléo-vallées et des bancs de la Manche orientale (1/50 000). B.R.G.M.

LekensWAH, Sejrup HP, Haflidason H, Petersen GO, Hjelstuen B, Knorr G (2005) Laminated sediments preceding Heinrich event 1 in the Northern North Sea and Southern Norwegian Sea: Origin, processes and regional linkage. Marine Geology 216(1-2):27-50 
Le Suavé R, (2000) Synthèse bathymétrique et imagerie acoustique. Zone économique exclusive (ZEE). Atlantique Nord-Est, IFREMER Brest

Lericolais G, Auffret J-P, Bourillet J-F (2003) The Quaternary Channel River: seismic stratigraphy of its palaeo-valleys and deeps. Journal of Quaternary Science 18(3-4):245260

Manley PL, Pirmez C, Busch W, Cramp A (1997) Grain-size characterization of Amazon fan deposits and comparison to seismic facies units. In: Flood RD, Piper DJW, Klaus A, Peterson LC (Eds) Proceding of the Ocean Drilling Program, Scientific Results pp35-52

Martin GB, Thorrold SR, Jones CM (2004) Temperature ans salinity effects on Sr incorporation in otoliths of larval spot (Leiostomus xanthurs). Can. J. Fish Aquat. Sci. 61:34-42

McCabe M, Clark PU (1998) Ice sheet variability around the North Atlantic Ocean during the last deglaciation. Nature 392:373-377

Migeon S, Weber O, Faugeres JC, Saint-Paul J (1999). SCOPIX: A new imaging system for core analysis. Geo-Marine Letters 18:251-255

Mojtahid M, Eynaud F, Zaragosi S, Scourse J, Bourillet J-F, Garlan T (2005) Palaeoclimatology and palaeohydrography of the glacial stages on Celtic and Armorican margins over the last 360000 yrs. Marine Geology 224(1-4):57-82

Richter TO, Lassen S, van Weering TCE, de Haas H (2001) Magnetic susceptibility patterns and provenance of ice-rafted material at Feni Drift, Rockall Trough: implications for the history of the British-Irish ice sheet. Marine Geology 173(1-4):37-54

Scourse JD, Hall IR, McCave IN, Young JR, Sugdon C (2000) The origin of Heinrich layers: evidence from $\mathrm{H} 2$ for European precursor events. Earth and Planetary Science Letters 182(2):187-195

Skene KI, Piper DJW, Hill PS (2002) Quantitative analysis of variations in depositional sequence thickness from submarine channel levees. Sedimentology 49:1411-1430

Turon JL, Bourillet J-F and Equipe ALIENOR 2004. Résultats préliminaires de la mission ALIENOR-MD141 - Partie 2, IPEV Brest FRANCE

Zaragosi S, Auffret GA, Faugères JC, Garlan T, Pujol C, Cortijo E (2000) Physiography and recent sediment distribution of the Celtic Deep-sea Fan, Bay of Biscay. Marine Geology 169:207-237

Zaragosi S, Eynaud F, Pujol C, Auffret GA, Turon J-L, Garlan T (2001) Initiation of the European deglaciation as recorded in the northwestern Bay of Biscay slope environments (Meriadzek Terrace and Trevelyan Escarpment): a multi-proxy approach. Earth and Planetary Science Letters 188(3-4):493-507

Zaragosi S, Le Suave R, Bourillet J-F, Auffret GA, Faugeres J-C, Pujol C, Garlan T (2001) The deep-sea Armorican depositional system (Bay of Biscay), a multiple source, ramp model. Geo-Marine Letters 20(4):219-232 


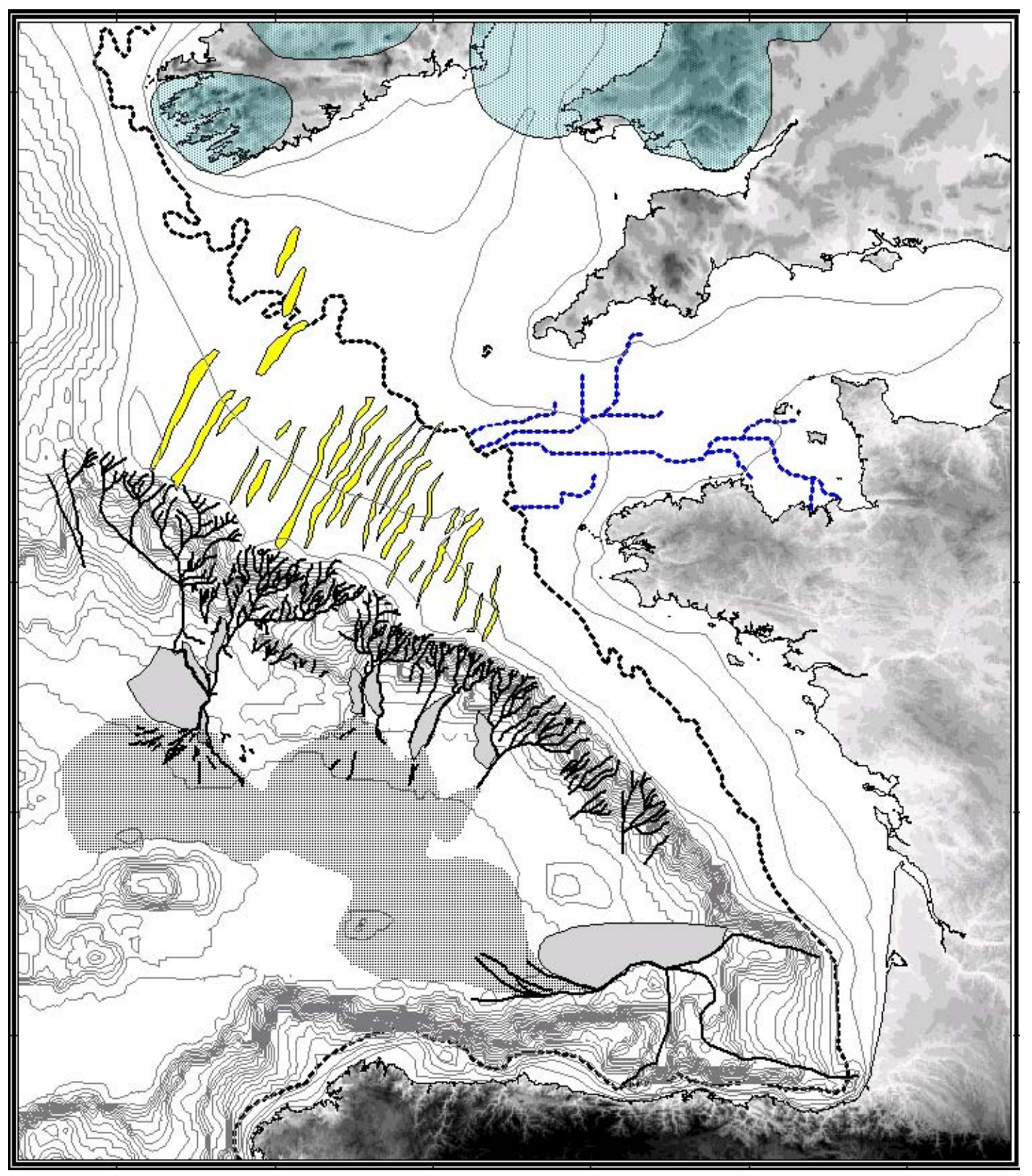

Fig. 1: Physiography of the Celtic-Armorican margin. Bathymetric contour intervals are $50 \mathrm{~m}$ on the shelf $(0$ $250 \mathrm{~m}), 500 \mathrm{~m}$ on the slope $(500-4000 \mathrm{~m})$ and $100 \mathrm{~m}$ on the deep sea $(4000-4900 \mathrm{~m})$. The English channel paleovalleys (1) and delta channels (2) are also depicted for the eastern part (Lericolais et al., 2003) and the western part of the shelf (Bourillet et al., 2003). (3) Coastline at 18,000 yrs ${ }^{14} \mathrm{C}$ BP (Bourillet at al., 2003); (4) B.I.S. full glacial extension (Lambeck, 1995); (5) Ice limits and ice stream across Celtic shelf at 21,000 yrs ${ }^{14} \mathrm{C}$ BP (Mc Cabe and Clark 1998; Scourse et al. 2000); (6) Celtic sand banks from Reynaud et al. (1999). Canyons incising the slope are organized into drainage basins converging to feeder channels: (a) 'Grande Sole' Drainage Basin, (b) 'Petite Sole' Drainage Basin, (c) 'la Chapelle' Drainage Basin and (d) 'Ouest Bretagne' Drainage Basin (Bourillet et al. 2003). Three mid-sized turbidite systems lie at a water depth of 4000 to 4 900m: (7) Cap Ferret turbidite system (Crémer et al. 1985; Faugères et al. 1998), (8) Armorican turbidite system (Le Suavé 2000, Zaragosi et al. 2001b) and (9) Celtic turbidite system (Droz et al. 1999; Auffret et al. 2000; Zaragosi et al. 2000). W. L.: Whittard Levee; C. F. L.: Cap Ferret levee. 


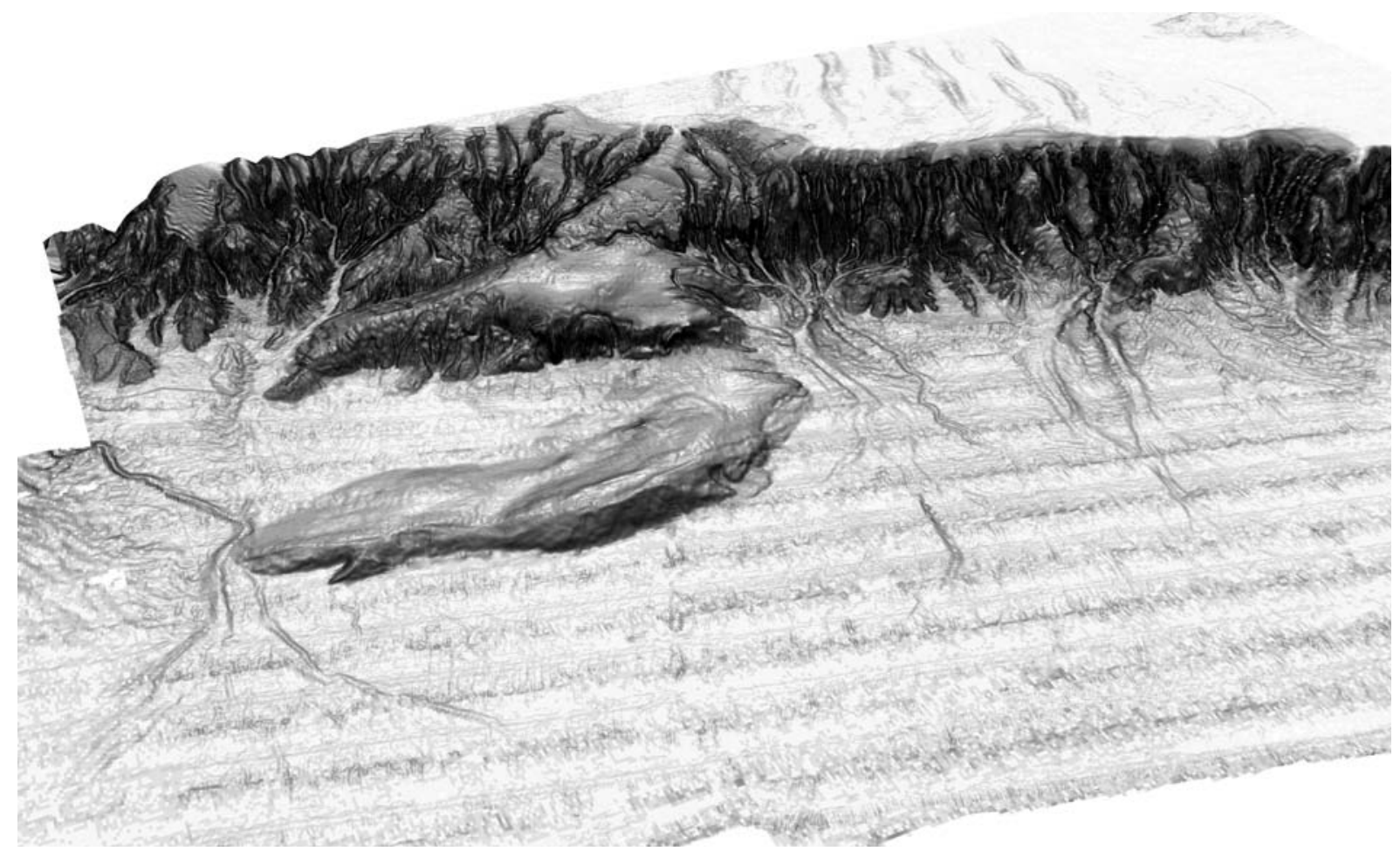

Fig. 2: Location of the studied cores with regards to the 3D representation of the margin (see Fig. 1 for limits map). S. L.: Shamrock Levee; G. L.: Guilcher levee; C. L.: Crozon Levee; A. L.: Audierne Levee. Bathymetric data are provided from the multibeam echosounder (SIMRAD EM 12) surveys of the area conducted onboard the R/V Atalante (IFREMER) during the cruises SEDIMANCHE (Bourillet and Loubrieu, 1995), SEDIFAN I (Auffret et al. 2000) and ZEE GASCOGNE I and II (Le Suavé 2000). 
$\%$ grains in the

$>150 \mu \mathrm{m}$ fraction
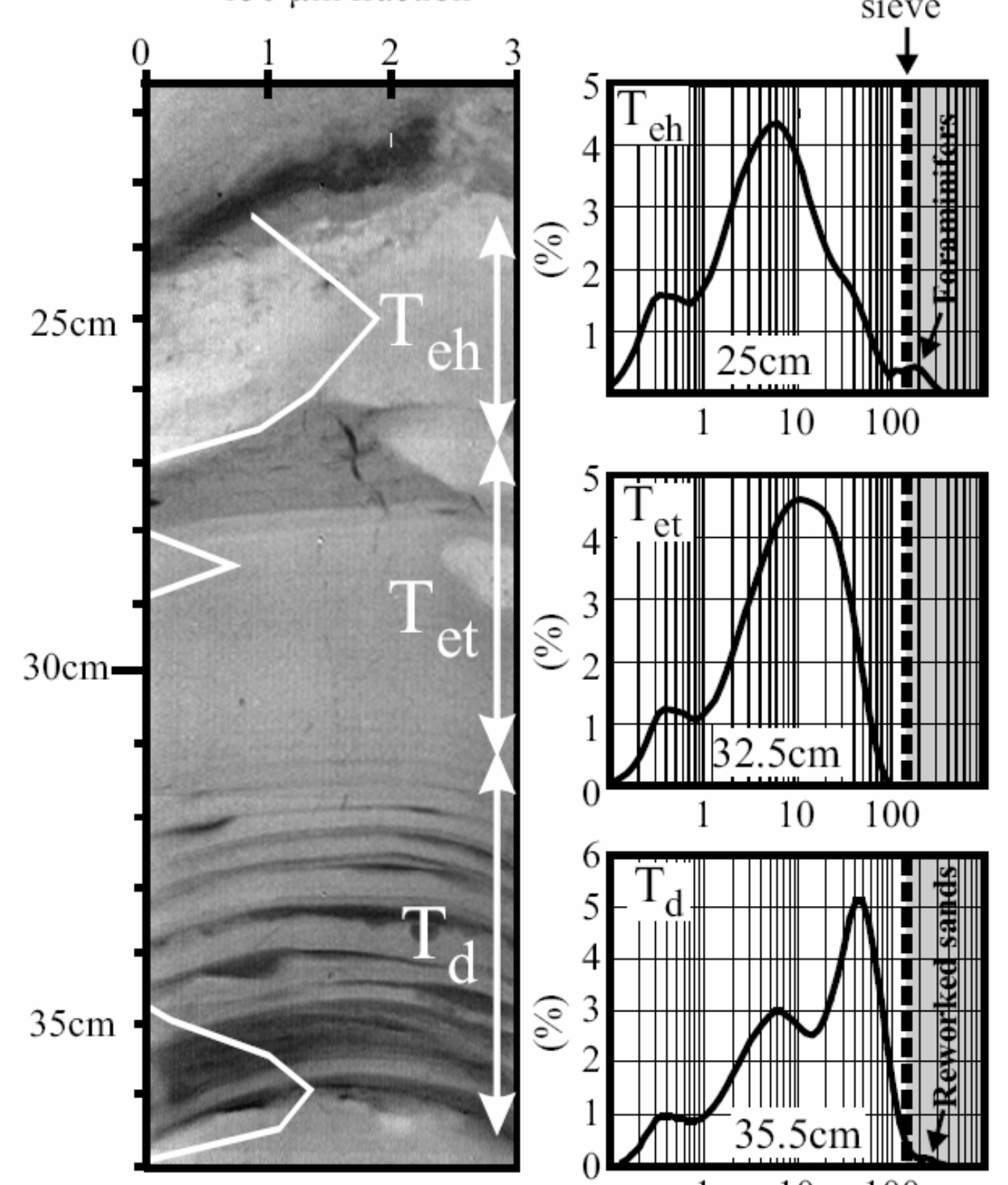

Xray imagery
$150 \mu \mathrm{m}$

sieve

$\downarrow$

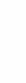

. 


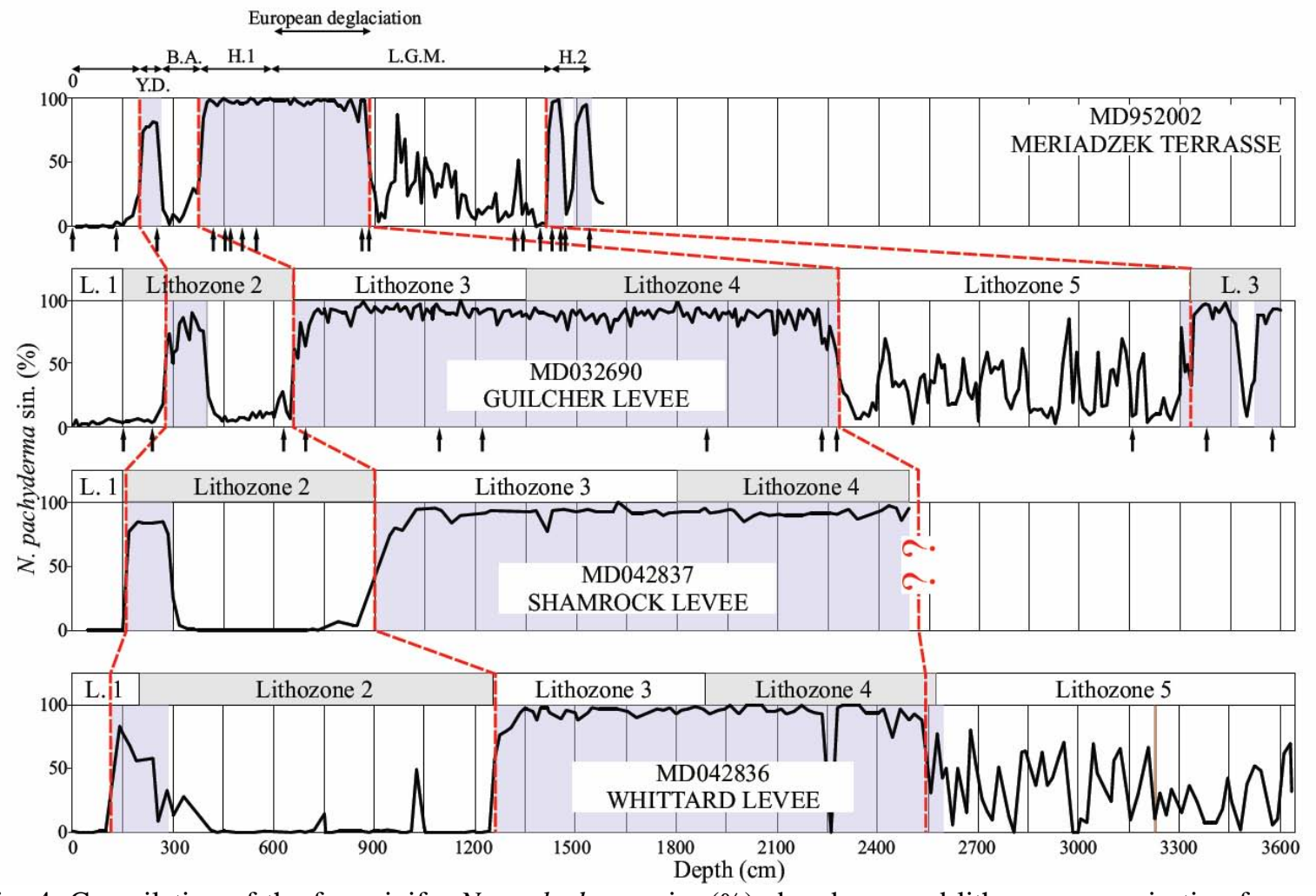

Fig. 4: Compilation of the foraminifer $N$. pachyderma sin. (\%) abundance and lithozone organisation for cores MD952002, MD032690, MD042837 and MD042836. Black arrows indicate AMS ${ }^{14} \mathrm{C}$ dating (Table 2). 


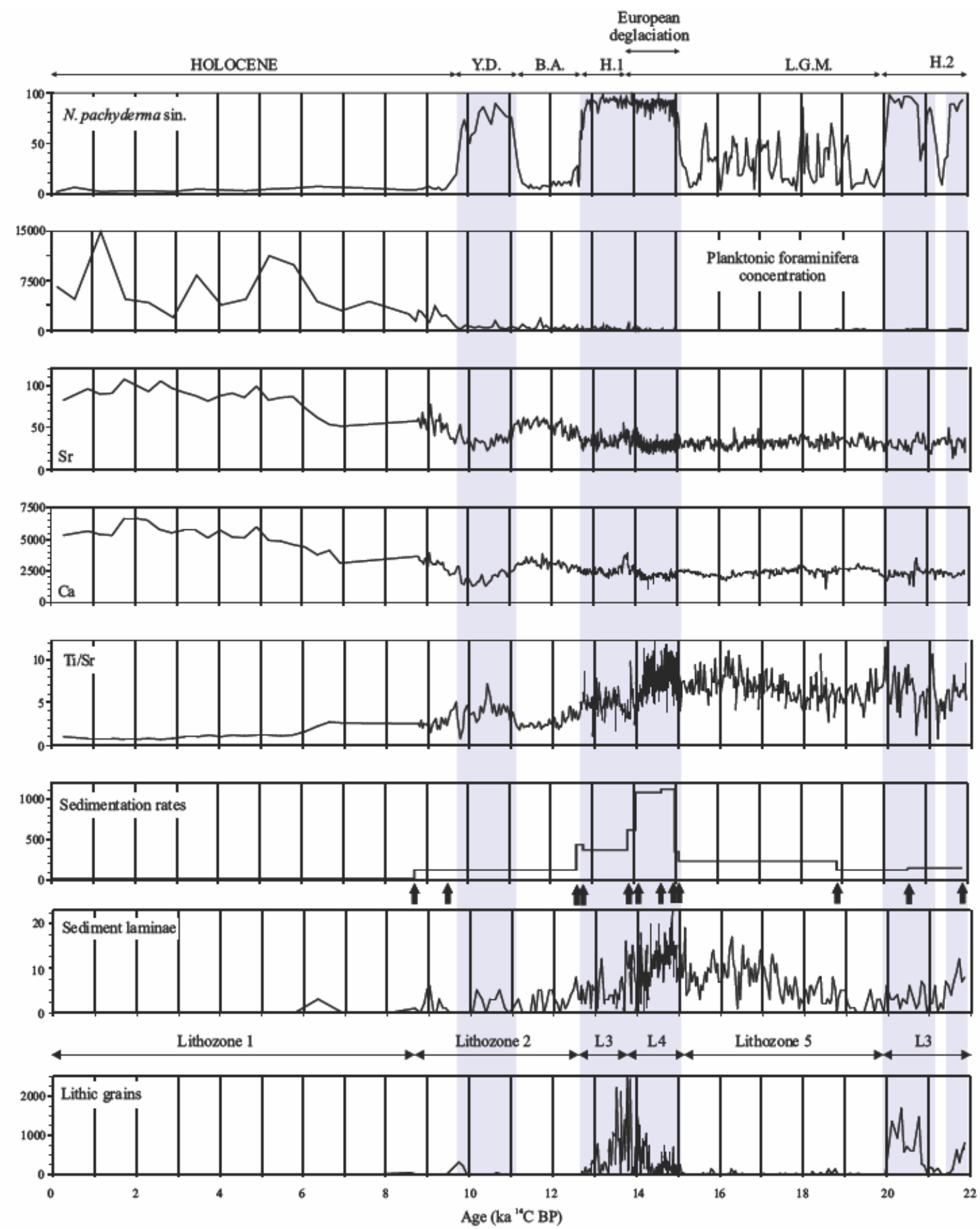

Fig. 5: Time scale of core MD032690 (Guilcher levee): abundance of the foraminifer N. pachyderma sin. (\%), planktonic foraminifera concentrations (number/g), Ca and Sr records obtained by XRF (cps), Ti/Sr ratio obtained by XRF, sedimentation rates $(\mathrm{cm} / \mathrm{kyr}$ ), frequency of sediment laminae (number/10 $\mathrm{cm}$ ), abundance of coarse $(>150 \mu \mathrm{m})$ lithic grains (grain/g). Black arrows indicate AMS ${ }^{14} \mathrm{C}$ dating (Table 2). Highlighted intervals mark polar sea-surface conditions. 


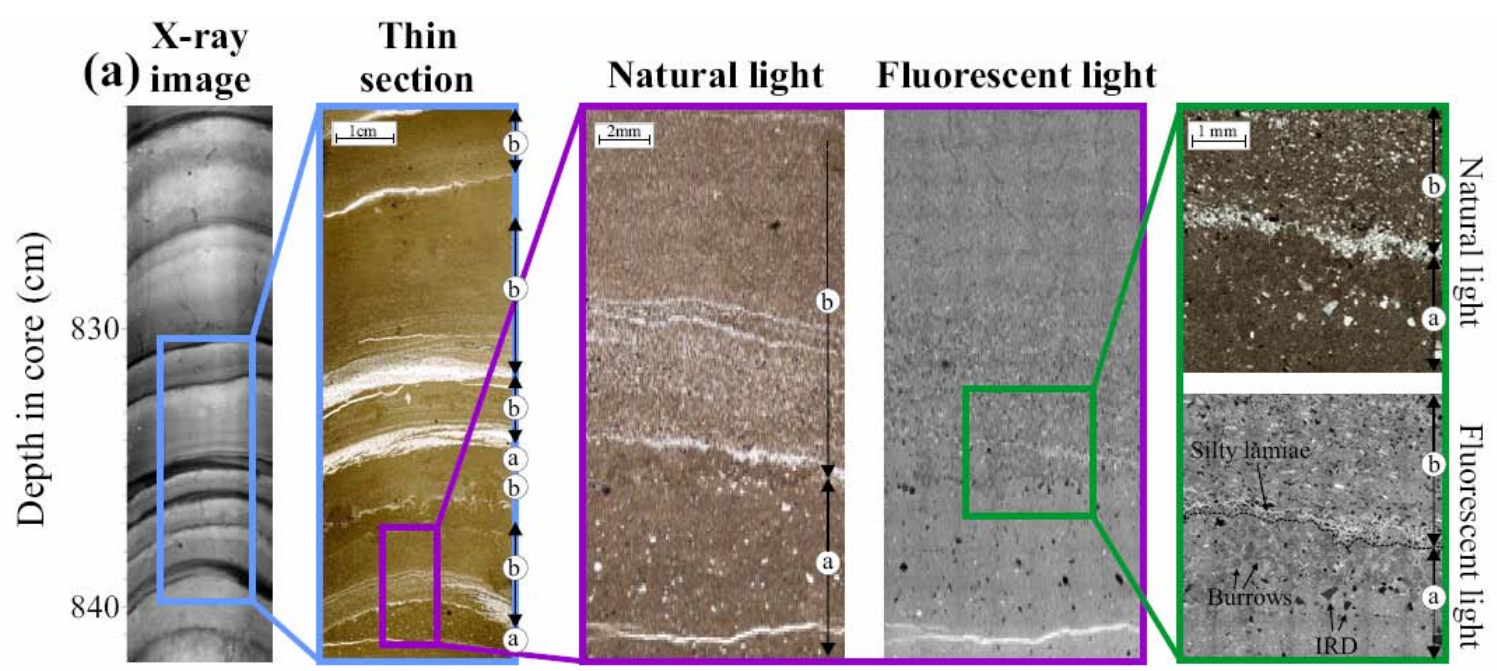

Lithozone 3

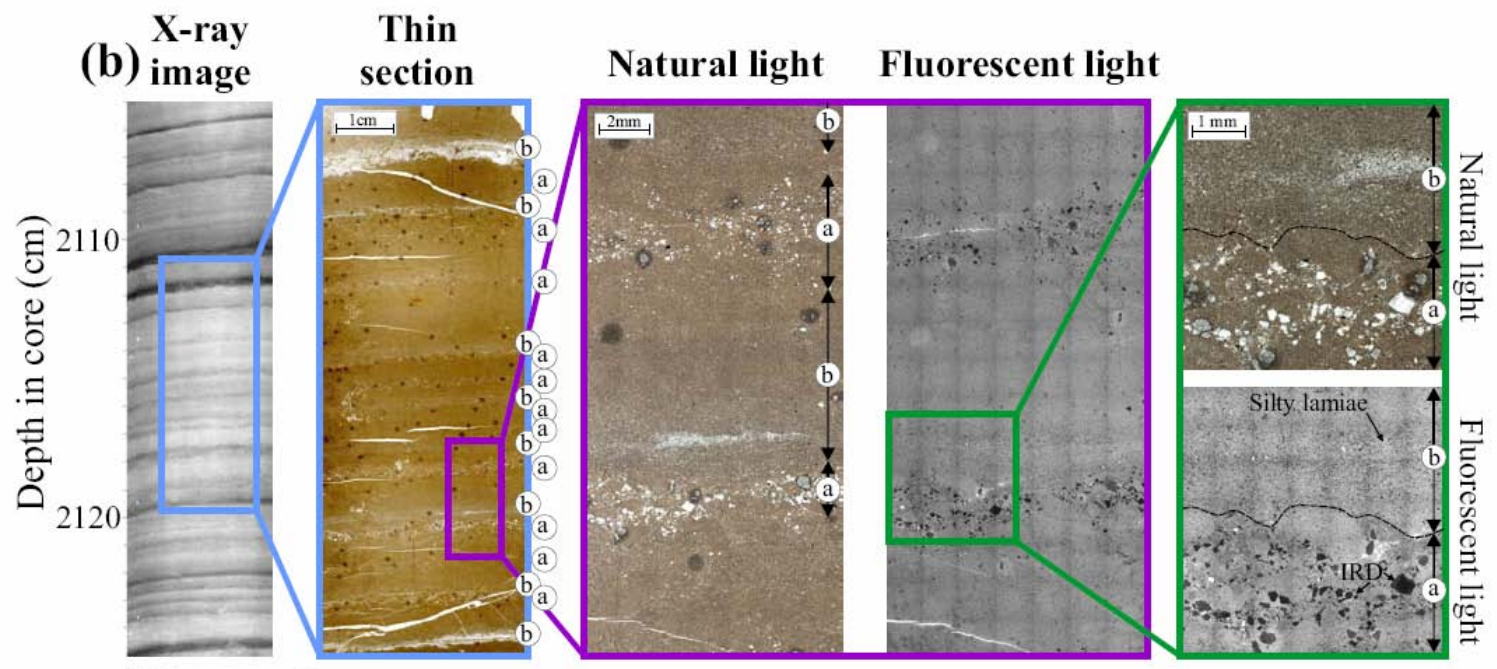

Lithozone 4

Fig.6: Different scale X-ray imagery and sediment thin section microphotography of MD03690 Lithozones 3 and 4. (a) Ice rafted rich clay layer; (b) fine-grained turbidite. 


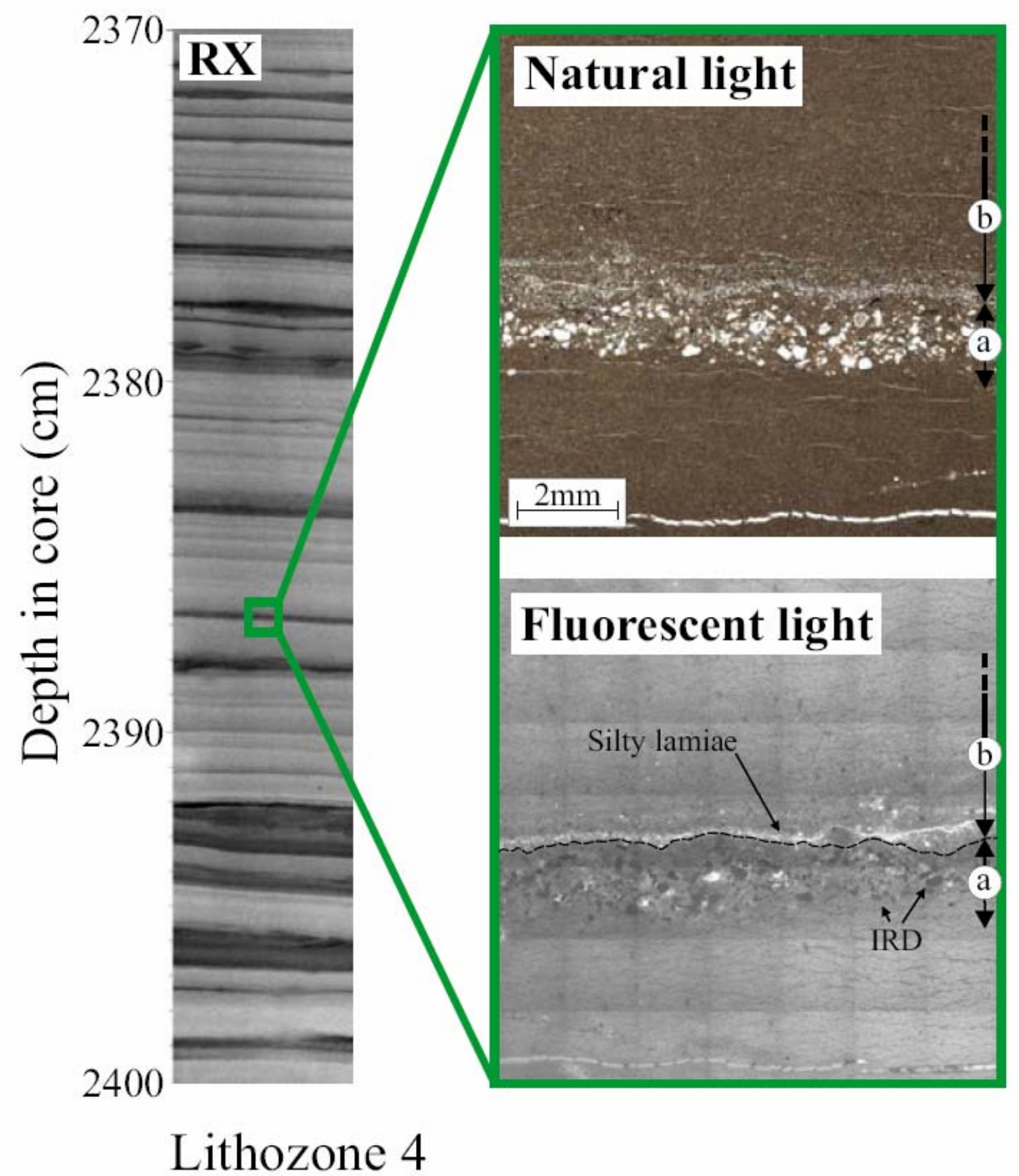

Fig. 7: X-ray imagery and sediment thin section microphotography of MD042836 Lithozones 4. (a) Ice rafted rich clay layers; (b) fine-grained turbidite. 


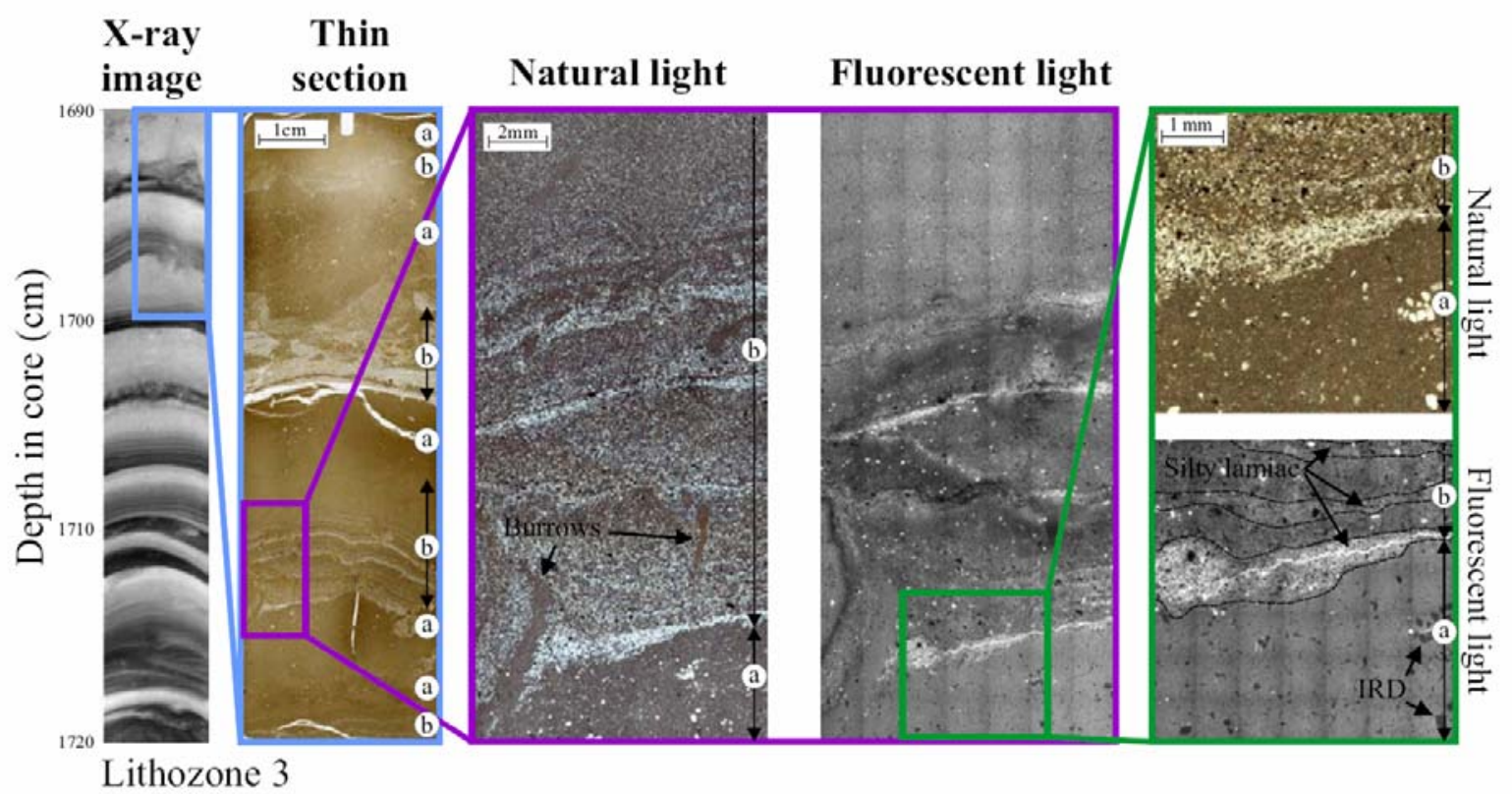

Fig.8: Different scale X-ray imagery and sediment thin section microphotography of MD042837 Lithozones 3. (a) Ice rafted rich clay layer; (b) fine-grained turbidite. 


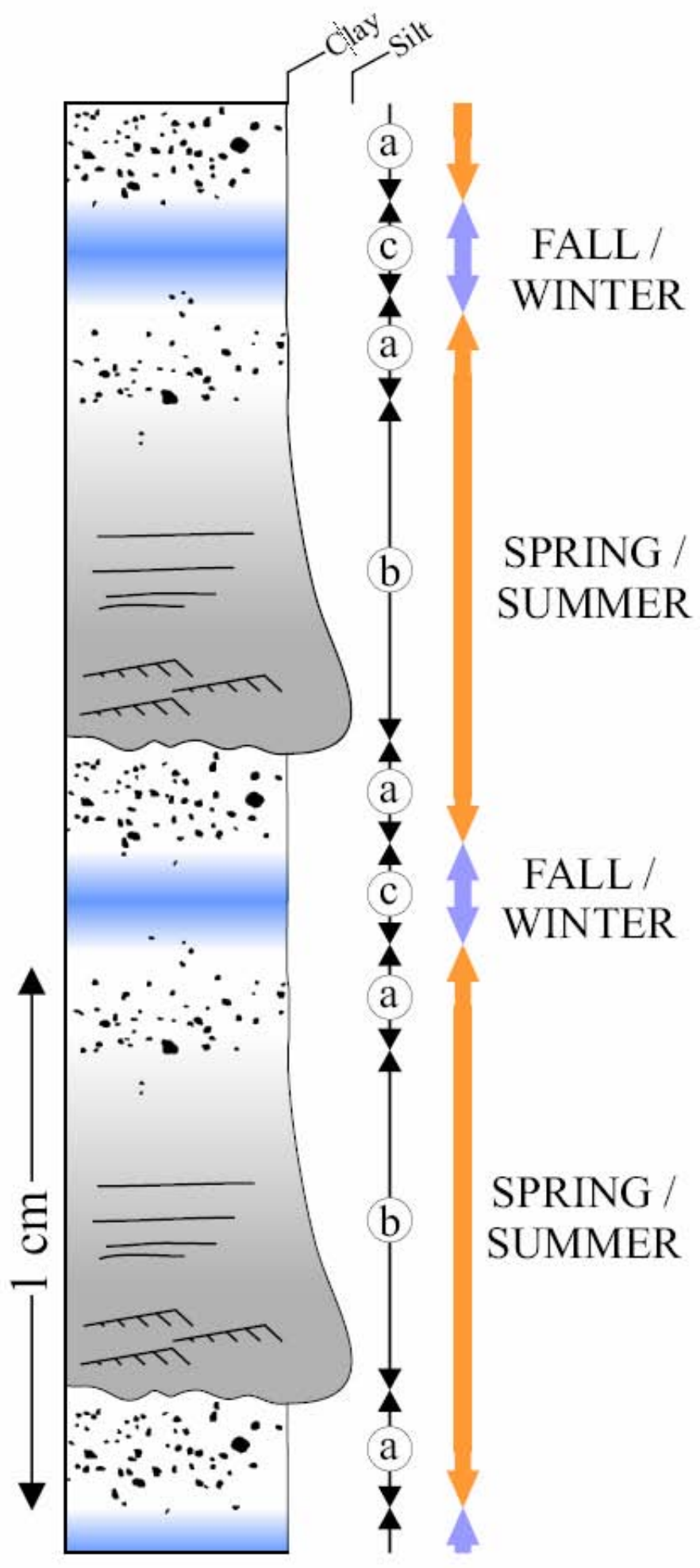

Fig.9: Conceptual model of a typical meltwater-induced fine-grained turbidite sequence. The unitary sequence is composed of two ice-rafted millimetric rich layers (a) spited by a fine-grained turbidite deposit (b). (c) corresponds to millimetric hemipelagic clay intervals. 
Tables

Location of cores

\begin{tabular}{|c|c|c|c|c|c|}
\hline Core number & Latitude & Longitude & Depth (m) & Cruise & Year Institute \\
\hline MD952002 & $47^{\circ} 27.12^{\prime} \mathrm{N}$ & $08^{\circ} 32.03^{\prime} \mathrm{W}$ & 2174 & MD 105 IMAGE 1 & 1995 IPEV - IFREMER \\
\hline MD032690 & $47^{\circ} 01.25^{\prime} \mathrm{N}$ & $07^{\circ} 44.99^{\prime} \mathrm{W}$ & 4340 & MD 133 SEDICAR & 2003 IPEV - IFREMER \\
\hline MD042836 & $47^{\circ} 16.57^{\prime} \mathrm{N}$ & $10^{\circ} 07.69^{\prime} \mathrm{W}$ & 4362 & MD 141 ALIENOR & 2004 IPEV - IFREMER \\
\hline MD042837 & $47^{\circ} 31.99^{\prime} \mathrm{N}$ & $09^{\circ} 44.01^{\prime} \mathrm{W}$ & 4176 & MD 141 ALIENOR & 2004 IPEV - IFREMER \\
\hline
\end{tabular}

Table 1: Core number, latitude, longitude, water depth and cruise details of cores investigated.

AMS ${ }^{14} \mathrm{C}$ ages origin

\begin{tabular}{|c|c|c|c|c|c|}
\hline Core number & $\begin{array}{l}\text { Depth } \\
\text { (cm) }\end{array}$ & $\begin{array}{l}\text { Conventional age BP } \\
\text { (reservoir correction) }\end{array}$ & $\begin{array}{l}\text { Calendar } \\
\text { age cal. BP }\end{array}$ & Species analysed & Origin \\
\hline MD95-2002 & 0 & $1660+/-70$ & 1624 & G. Bulloides & LSCE-99360 \\
\hline MD95-2002 & 140 & $9080+/-90$ & 10329 & G. Bulloides & LSCE-99361 \\
\hline MD95-2002 & 240 & $10790+/-100$ & 12809 & N. pachyderma s. & LSCE-99362 \\
\hline MD95-2002 & 420 & $13330+/-130$ & 15798 & N. pachyderma s. & LSCE-99363 \\
\hline MD95-2002 & 454 & $13800+/-110$ & 16426 & N. pachyderma s. & LSCE-99364 \\
\hline MD95-2002 & 463 & $14020+/-120$ & 16709 & N. pachyderma s. & LSCE-99365 \\
\hline MD95-2002 & 510 & $14170+/-130$ & 16897 & N. pachyderma s. & LSCE-99366 \\
\hline MD95-2002 & 550 & $14430+/-70$ & 17327 & N. pachyderma s. & Artemis-003242 \\
\hline MD95-2002 & 869 & $14900+/-70$ & 18241 & N. pachyderma s. & Artemis-003243 \\
\hline MD95-2002 & 875 & $14880+/-160$ & 18224 & N. pachyderma s. & Artemis-003244 \\
\hline MD95-2002 & 1320 & $18450+/-90$ & 22062 & G. Bulloides & Artemis-003245 \\
\hline MD95-2002 & 1340 & $19030+/-100$ & 22514 & G. Bulloides & Artemis-003246 \\
\hline MD95-2002 & 1390 & $20220+/-80$ & 24690 & G. Bulloides & Artemis-003247 \\
\hline MD95-2002 & 1424 & $19840+/-60$ & 23777 & N. pachyderma s. & Beta-123696 \\
\hline MD95-2002 & 1453 & $20030+/-80$ & 23984 & N. pachyderma s. & Beta-123698 \\
\hline MD95-2002 & 1464 & $20200+/-80$ & 24174 & N. pachyderma s. & Beta-123699 \\
\hline MD95-2002 & 1534 & $21850+/-70$ & 25734 & N. pachyderma s. & Beta-123697 \\
\hline MD95-2002 & 1610 & $24010+/-250$ & 28222 & N. pachyderma s. & Beta-99367 \\
\hline MD95-2002 & 1664 & $25420+/-230$ & 29830 & N. pachyderma s. & Beta-99368 \\
\hline MD03-2690 & 151 & $8730+/-60$ & 9722 & G. Bulloides & Artemis-001894 \\
\hline MD03-2690 & 245 & $9450+/-60$ & 10603 & G. Bulloides & Artemis-003233 \\
\hline MD03-2690 & 626 & $12620+/-60$ & 14790 & G. Bulloides & Artemis-003234 \\
\hline MD03-2690 & 692 & $12770+/-70$ & 14972 & N. pachyderma s. & Artemis-003235 \\
\hline MD03-2690 & 1094 & $13840+/-70$ & 16266 & N. pachyderma s. & Artemis-003236 \\
\hline MD03-2690 & 1213 & $14030+/-70$ & 16495 & N. pachyderma s. & Artemis-003237 \\
\hline MD03-2690 & 1885 & $14650+/-70$ & 17241 & N. pachyderma s. & Artemis-003238 \\
\hline MD03-2690 & 2233 & $14960+/-70$ & 17613 & N. pachyderma s. & Artemis-003239 \\
\hline MD03-2690 & 2276 & $15080+/-70$ & 17760 & N. pachyderma s. & Poznań Radiocarb. Lab. \\
\hline MD03-2690 & 3156 & $18850+/-100$ & 22234 & G. Bulloides & Artemis-003240 \\
\hline MD03-2690 & 3376 & $20560+/-70$ & 24236 & N. pachyderma s. & Artemis-003241 \\
\hline MD03-2690 & 3576 & $21880+/-120$ & 25770 & N. pachyderma s. & Poznań Radiocarb. Lab. \\
\hline
\end{tabular}

Table 2: AMS ${ }^{14} \mathrm{C}$ ages with calendar correspondences (Bard, 1998) 